\title{
Age and lunar cycle predict harbor porpoise bycatch in the south-western Baltic Sea
}

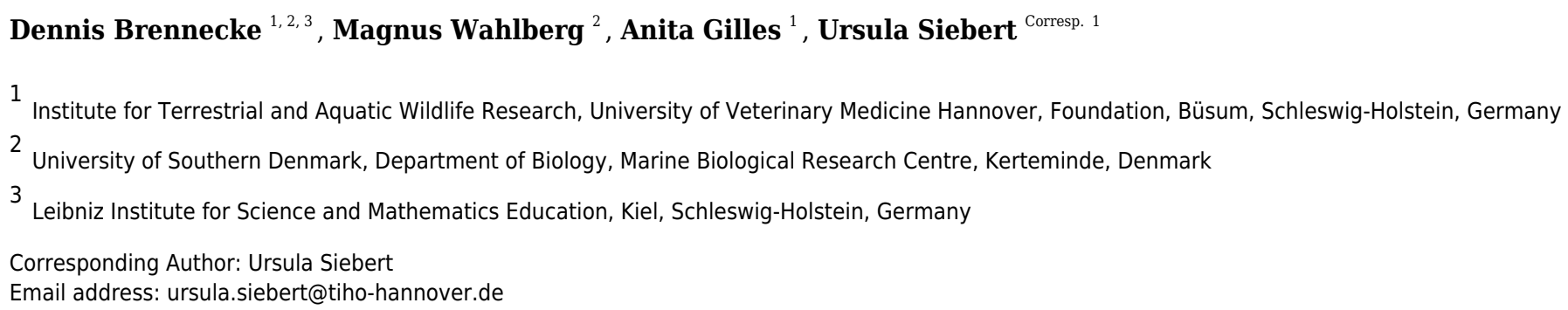

The harbor porpoise, Phocoena phocoena, is the only cetacean regularly occurring in the Baltic Sea. During the last decades, several anthropogenic activities have affected porpoises in the Baltic region. Most notably is bycatch in static fishing gear, such as gill nets, which is the main human-induced cause of death in odontocetes. There is still considerable uncertainty about which factors influence the amount of bycatch. In the present study, we reviewed bycatch data collected from 1987 to 2016 from the southwestern Baltic Sea. There was a significant difference in bycatch due to seasonality and region, and there was a higher bycatch rate in juveniles than in adults. The only abiotic factor associated with bycatch was the lunar cycle, with more animals bycaught during a full moon. These results improve our understanding of which biotic and abiotic factors are associated with bycatch of Baltic harbor porpoises, which can be used to strengthen conservation endeavors such as managing fishing efforts. 


\section{Age and lunar cycle predict harbor porpoise bycatch 2 in the south-western Baltic Sea}

3

4

5

6

7

\section{Dennis Brennecke ${ }^{1,2,3}$, Magnus Wahlberg ${ }^{2}$, Anita Gilles ${ }^{1}$, Ursula Siebert ${ }^{1}$}

${ }^{1}$ Institute for Terrestrial and Aquatic Wildlife Research, University of Veterinary Medicine Hannover, Foundation, Büsum, Germany

${ }^{2}$ Department of Biology, Marine Biological Research Centre, University of Southern Denmark, Kerteminde, Denmark

${ }^{3}$ Leibniz Institute for Science and Mathematics Education, Kiel, Germany

Corresponding Author:

Ursula Siebert

Werftstr. 6, Büsum, 25761, Germany

Email address: Ursula.Siebert@tiho-hannover.de 


\section{Abstract}

42 The harbor porpoise, Phocoena phocoena, is the only cetacean regularly occurring in the Baltic

43 Sea. During the last decades, several anthropogenic activities have affected porpoises in the

44 Baltic region. Most notably is bycatch in static fishing gear, such as gill nets, which is the main

45 human-induced cause of death in odontocetes. There is still considerable uncertainty about which

46 factors influence the amount of bycatch. In the present study, we reviewed bycatch data collected

47 from 1987 to 2016 from the south-western Baltic Sea. There was a significant difference in

48 bycatch due to seasonality and region, and there was a higher bycatch rate in juveniles than in

49 adults. The only abiotic factor associated with bycatch was the lunar cycle, with more animals

50 bycaught during a full moon. These results improve our understanding of which biotic and

51 abiotic factors are associated with bycatch of Baltic harbor porpoises, which can be used to

52 strengthen conservation endeavors such as managing fishing efforts.

53

\section{Introduction}

55

56

57

58

59

60

61

62

63

64

65

66

67

68

69

70

71

72

73

74

75

76

77

78

79

80
The Baltic Sea is severely altered by anthropogenic activities and, therefore, one of the most intensely studied coastal areas worldwide (Korpinen et al., 2012; Reusch et al., 2018). Intensive fisheries, shipping, military activities, and pollution are collectively notorious threats to Baltic Sea fauna (HELCOM, 2018). Incidental catches during fishing operations, i.e., bycatch, are considered the greatest global threat to cetaceans (Read et al., 2006; Reeves et al., 2013); especially to small cetaceans, like the harbor porpoise, Phocoena phocoena (Brownell et al., 2019). It is therefore highly likely that bycatch has a substantial impact on the population size of Baltic harbor porpoises (van Beest et al., 2017).

There have been considerable conservation efforts regarding this species due to its vulnerability to human disturbance (Siebert et al., 2006; Carlén et al., 2018; Carlén et al., 2021). For all three populations in the Baltic region, including the North Sea population that occurs from northern Kattegat to the North Sea, assessed bycatch rates are likely above $1.7 \%$ of the population size, which by ASCOBANS has been defined as the maximum sustainable level for anthropogenic mortality (Vinther, 1999; Berggren et al., 2004; Vinther and Larsen, 2004; Bjørge et al., 2013; Moan et al., 2020). Even though some of these bycatch estimates are old and associated with large errors, they call for great concern regarding the impact of bycatch of both small and large populations of harbor porpoises (Rogan et al., 2021). In addition, it has been estimated that the critically endangered Baltic Proper population can only sustain a maximum of 0.7 animals per year killed by human activities (North Atlantic Marine Mammal Commission \& Norwegian Institute of Marine Research, 2019). In case of such small and threatened populations any bycatch of animals may therefore be disastrous for the population. Efficient solutions to the porpoise bycatch problem involve changing fishing practices, including time-area fishing closures (van Beest et al., 2017), use of alternative fishing gear (Königson et al., 2015), or improving the acoustic detectability of gillnets (Kratzer et al., 2020). To make mitigation measures as efficient as possible, it is important to know the environmental context in the area where bycatch is occurring. For example, the soundscape experienced by the animals may

PeerJ reviewing PDF | (2021:03:58695:3:0:NEW 30 Aug 2021) 
81 impact the risk of bycatch. Animals may be distracted by increased levels of sound, or such

82

83

84

85

86

87

88

89

90

91

92

93

94

95

96

97

98

99

100

101

102

103

104

105

106

107

108

109

110

111

112

113

114

115

116

117

118

119

sounds may mask the porpoises' abilities to detect the gill nets by echolocation. Negative effects of underwater noise disrupting the behavior of harbor porpoises have been documented (Tougaard et al., 2009; Dähne et al., 2013; Dyndo et al., 2015; Wisniewska et al., 2018). It is conceivable that also natural sounds can disrupt harbour porpoise behaviour. For example, noise generated by extreme weather events, such as heavy rain can increase noise levels by up to $50 \mathrm{~dB}$ above the background noise level across a broad range of frequencies (Nystuen, 1986). In addition, wind may also create distracting sounds (Pensieri et al., 2015). Furthermore, there are many environmental drivers for fish activity such as anti-predator and food search behavior on a fine scale, and diel and seasonal rhythms on a larger scale (Løkkeborg and Fernö, 1999). Many species of fish have activity patterns steered by moon phases, and therefore it is conceivable that also porpoise behavior could be affected by changes in lunar illumination, which may therefore affect the risk of bycatch (Takemura et al., 2004; Horký et al., 2006; Celik and Celik, 2011). Lunar influence on cetaceans has been observed in indo-pacific humpback dolphins (Wang et al. 2015) and also in the dive behavior and spatial area used by pilot whales (Owen et al. 2019). Thus, perhaps lunar cycles may also influence porpoises.

To date, it is unknown which abiotic, biotic and/or anthropogenic factors might correlate with the risk of a porpoise being bycaught. In the present study, we analyzed a long-term dataset of 30-year bycatch data from the south-western Baltic Sea. Besides seasonal and spatial trends, we investigated whether age and sex play an important role in the likelihood of animals being bycaught. In addition, we examined whether harbor porpoise abundance and gillnet fishing activities affect bycatch. The role of environmental conditions, such as wind, precipitation and lunar cycle on bycatch events was further evaluated.

\section{Materials \& Methods}

\section{Data collection}

From 1987 to 2016, 140 bycaught harbor porpoises, collected by the stranding network of Schleswig-Holstein along the German Baltic Sea coast (Siebert et al., 2006), were handed over by fishermen and brought to the Institute for Terrestrial and Aquatic Wildlife Research (ITAW), University of Veterinary Medicine Hannover, Foundation, Germany for necropsy (Siebert et al., 2001, 2020; Wünschmann et al., 2001). Fishermen are obliged to report bycatch of cetaceans by law. Data on location, date of bycatch, age, body length, weight and sex of the bycaught animals were collected. Age was preferably determined using teeth by counting the annual growth layers, or (if dental age determination was not possible) by measuring the body length of the animals (Myrick et al., 1983; Kremer, 1987; Lockyer, 1995; Siebert, 2001). Animals were categorized in age groups based on Siebert $(2001 ; 2020)$ : Neonates and calves: $\leq 0.5$ years old, juveniles/subadults: $0.5-4$ years old and adults: $>4$ years old. Four animals were excluded from the data set for the seasonal distribution analysis due to inconclusive age determination. Only bycatch events notified directly by fishermen and confirmed by necropsy were used. While

Peer) reviewing PDF | (2021:03:58695:3:0:NEW 30 Aug 2021) 
120

121

122

123

124

125

126

127

128

129

130

131

132

133

134

135

136

137

138

139

140

141

142

143

144

145

146

147

148

149

150

151

152

153

154

155

156

157

158

159

reporting a bycatch event, a few fishermen also reported the used net type (single wall and three wall gill nets), target fish (mainly cod and flatfish) and water depth (10-25m).

In order to put reported bycatch events in the context of harbor porpoise abundance estimates in the region, data from aerial surveys conducted regularly in the area following linetransect distance sampling methodology, were used. Hereby, only surveys conducted in the stratum Kiel Bight from 2002-2015 were considered (see stratum "E" in Scheidat et al., 2008). To evaluate the possible seasonal change between bycatch and fishing effort, we included data from an analysis of the fisheries in the south-western Baltic Sea between 2010 and 2012 using monthly averages of fishing effort (Dorrien et al., 2013). Only fishing boats larger than $8 \mathrm{~m}$ using gillnets were considered, since fishermen with these boats are obliged to report fishing activities effort, that can later be used to calculate the fishing effort, in a logbook.

In order to determine, if weather conditions could have been associated with bycatch events, we analyzed meteorological data provided by the German National Meteorological Service (Deutscher Wetterdienst, DWD). During the time period from 1987 to 2016 we obtained information on daily precipitation ( $\mathrm{mm}$ ), daily maximum wind speed data up to $15 \mathrm{~m} / \mathrm{s}$ and mean daily cloud coverage (oktas) from nine different weather stations (Kiel lighthouse, Fehmarn, Glücksburg, Schönhagen, Kiel-Holtenau, Travemünde, Flensburg, Hohwacht, Lübeck Blankensee) closest in distance to each bycatch event. Weather data was not available for each bycatch event.

We also analyzed if the lunar cycle correlated with bycaught animals. Data on the lunar cycle were obtained from the US Naval Observatory (USNO, http:aa.usno.navy.mil/data) at $54^{\circ} 30^{\prime} \mathrm{N}, \mathrm{E} 10^{\circ} 20^{\prime} \mathrm{E}$ (this location is within $40 \mathrm{~nm}$ from any of the bycatch events studied here), one hour ahead of Greenwich Mean Time (GMT) which corresponds to German time without daylight saving. For each bycatch event, the percentage of illumination of the moon's visible disk was categorized into eight phases as follows: i) new moon; ii) waxing crescent; iii) first quarter; iv) waxing gibbous; v) full moon; vi) waning gibbous; vii) last quarter; and viii) waning crescent.

\section{Statistical analyses}

We conducted regressions using polynomials of different orders for the bycatch time series to assess whether bycatch had changed over the 30-year period and whether bycatch changed with porpoise abundance between 2002 and 2015. We used partial F-tests with the ANOVA command in $\mathrm{R}$ to determine which polynomial model provided the best fit.

We checked for a statistical significance difference using Chi-squared tests between the bycatch events in (a) different years, (b) different months and (c) different regions, and (d) during different lunar phases in which bycatch occurred. Five animals were excluded from the spatial analysis due to unknown bycatch location. For all Chi-squared tests we calculated the expected frequencies by dividing the total sample size by the number of groups. In order to test for significant differences between wind speed and precipitation during days with and without bycatch, we used ANOVA. Statistical analyses were performed using R software, version 3.5.2 
160 (R Core Team, 2018). Data visualization was conducted by "ggplot2" package, version 3.2.1, in 161 R software (Wickham, 2016).

162

163

164

165

166

167

168

169

170

171

172

173

174

175

176

177

178

179

180

181

182

183

184

185

186

187

188

189

190

191

192

193

194

195

196

197

198

199

\section{Results}

The highest number of bycaught animals was observed in the first decade of the time series (1987 - 1996), with an average of 7.4 individuals per year, reaching a maximum of 22 animals in 1991 (Fig. $1, X^{2}=110, \mathrm{~N}=26,140$ ), $\mathrm{p}<0.0001$ ). From 2015 onwards, bycatch increased to more than eight animals per year. Polynomial regression analysis revealed a significant relationship between the number of bycaught animals and year $\left(\mathrm{R}^{2}=0.5, \mathrm{~F}_{5,21}=4.2, \mathrm{p}<0.01\right)$. When seasonal differences were investigated by binning the numbers of bycaught porpoises by different months, $69.3 \%$ of all porpoises were bycaught from July to November, with the highest number observed in August with 29 animals $\left(X^{2}=61, N=11,140, \mathrm{p}<0.0001\right)$. Juveniles were bycaught more frequently (73\%) followed by adults (20\%) and neonates (7\%). Most juveniles (71\%) were bycaught between July and November. Neonates were only bycaught between July and October (Fig. 2). When comparing monthly binned data for female and male bycaught animals, there was no significant difference in the amount of bycaught animals (i.e. males: $47 \%$ and females: $53 \%, X^{2}=0.6, N=1,139, \mathrm{p}=0.45$ ), except for a $80 \%$ female bycatch in May.

The majority of bycatch occurred in Eckernförde Bight and Schlei (Fig. 3 and Table 1; $21.5 \%$ and $20 \%$ of total bycatch, respectively, $\left.X^{2}=34, N=7,135, \mathrm{p}<0.0001\right)$. There was no clear relationship between abundance of porpoises and number of bycaught animals per season between 2002 and $2015\left(\mathrm{R}^{2}=0.24, \mathrm{~F}_{2,16}=2.632, \mathrm{p}=0.10\right)$. While gillnet fishing effort increased slightly in the fall from September to November, bycatch was higher from July to November. In August, the bycatch rate, i.e. bycatch per fishing effort, was four porpoises per 100 days at sea (Fig. 2).

There were no significant differences between the maximum wind speed of days with and without bycatch (ANOVA, $F_{1,52787}=0.003, p=0.96$ ), and between the daily precipitation during bycatch events and days without any bycatch (ANOVA, $F_{1,68433}=0.934, p=0.33$; Fig. 4). The majority of bycatch (28.6\%) occurred during the lunar phase 5 (full moon; Fig. $5, X^{2}=49, \mathrm{~N}=7$, $140, \mathrm{p}<0.0001)$. The cloud cover during these full moon bycatch events was in $15 \%$ of the cases $\geq 6$ oktas (mean daily cloud coverage). There was more bycatch during moonlight (with lunar illumination $>50 \%)$ nights $(65 \%)$ than during dark nights $(35 \%)$.

\section{Discussion}

Every year, numerous harbor porpoises end up as bycatch in fishing operations. Even though bycatch has been reported for decades, there is still considerable uncertainty regarding possible factors that might be correlated with bycatch. From our data it is clear that bycatch is particularly a major threat to juvenile harbor porpoises in the south-western Baltic Sea, and that the majority of harbor porpoises were bycaught during a full moon and between July and November. Even though the total number of bycaught harbor porpoises remains unknown, bycatch may seriously affect the population size of porpoises in these waters, since the majority of bycaught animals 
200

201

202

203

204

205

206

207

208

209

210

211

212

213

214

215

216

217

218

219

220

221

222

223

224

225

226

227

228

229

230

231

232

233

234

235

236

237

238

239

were not sexual mature. The highest number of bycaught animals in our study was observed in the first decade of data collection (i.e. between 1987 - 1996), when bycatch was more than double the one during the following decades. In the Gulf of Maine, a similar decline in harbor porpoise bycatch was attributed to several mitigation measures, including time-area closures and the use of acoustic alarms, as well as to a declined gill-net fishing effort (Read et al., 2006). It is possible that a reduction in bycatch in European waters could have been caused by similar mitigation measures and a similar decline in the gill net fishery. However, it is also possible that regulations of bycatch as well as fishing catch limits in all EU waters initiated in the 1990s and during the last decade in the Baltic Sea to improve the poor state of Baltic cod stocks, have influenced the willingness of fishermen to register bycaught animals. Considering that our data are of opportunistic nature using reported bycatch delivered by fishermen, the reported bycatch decrease may be related to fishermen reporting fewer animals.

To avoid such possible conflicts of interest in the future, a voluntary agreement between fishermen and the Schleswig-Holstein Ministry of Energy, Agriculture, the Environment, Nature and Digitalization was established in 2014 which consists of an anonymous "pick-up service" for bycaught harbor porpoises (OIC, 2015). With 8 animals in 2015 and 10 animals in 2016, this measure seems to make a difference for the willingness of reporting by fishermen. The increase in the number of bycaught animals since 2015 is likely caused by this new agreement rather than a change in the number of animals being caught in fishing gear.

Our study reveals a high bycatch rate of individuals younger than four years old, which is consistent with previous findings (e.g., Berggren, 1994; Kinze, 1994; Kock and Benke, 1996; Tregenza et al., 1997). It is likely that the emphasis of young porpoises being bycaught is not only explained by their disability to perceive nets as a threat but also to them being more curios than adults. It is still unknown at which age young animals separate from their mothers, and whether juvenile animals move around alone, or in mixed age groups. It has been reported that during their first 10 months of life harbor porpoise calves spend more than $50 \%$ of the time in close proximity with their mothers (Palacino González, 2019).

Considering the lack of experience of juveniles raises the question if there is any learning effect involved in net interactions, meaning that older porpoises are better in avoiding being caught in a net. This would imply that many older animals may have experienced disentanglement themselves from nets when younger and then learned from this dangerous experience, or also if they witnessed others being bycaught and thereby learned to perceive the net as a danger. During necropsies at ITAW over the last 30 years, only a few animals showed scars indicating a previous interaction with fishing gear. In general, assessment of interactions with nets among stranded animals is a difficult task and needs trained veterinary pathologists. Not all bycaught animals show net marks, and for animals in a state of advancing decomposition net marks are difficult to identify (IJsseldijk et al., 2020; Siebert et al., 2020).

The predominance of young porpoises among bycaught animals could also be caused by dietary differences between age groups (Perrin et al. 1994; Kastelein et al., 2000). Adult porpoises feed on larger fish, such as flatfish and gadoids, while younger ones prefer smaller 
240 sized prey like gobies and sprat (Benke et al., 1998; Wisniewska et al., 2016). Also, the age 241 structure of stranded porpoises is highly biased towards young animals (Siebert et al., 2020). For 242 natural populations, a similar bias towards neonates and juveniles was corroborated by the killing 243 of 41 harbor porpoises, predominately juveniles, through detonations of naval mines in August 2442019 (Siebert et al. 2020). Even though harbor porpoises can reach an age of 20-25 years, the 245 average longevity for females in the German Baltic Sea is less than 4 years, i.e. before or shortly

246

247

248

249

250

251

252

253

254

255

256

257

258

259

260

261

262

263

264

265

266

267

268

269

270

271

272

273

274

275

276

277

278

279 after reaching maturity (Kesselring et al., 2018). As there is a predominance of young porpoises in the bycatch as well as in the population, it may also be that the actual bycatch risk for each age class is rather constant.

According to our study, there was no difference in the vulnerability to bycatch between males and females. The high incidence of bycaught adult females in May could be related to the calving season. According to Lockyer (2003) and Hasselmeier (2004), the annual life cycle of harbor porpoises is divided into mating (from July to September), calving (from May to August) and nursing (from September to April). Calving and nursing occur mainly in shallow areas and, thus, females restrict their foraging to those areas and will not dive very deep or search for food in large areas (Koschinski, 2001; Santos and Pierce, 2003; Wisniewska et al., 2016). Many gillnets are found in coastal waters, a preferred habitat for female-calf pairs (Funk et al., 2020). Consequently, the risk of being bycaught in a gillnet is much higher for adult females than males during the first months after birth (Herr, 2009).

Although bycatch occurs year-round, its monthly distribution in this specific area suggests a strong seasonality, with the highest occurrence between July and November, as also found by Kock and Benke (1996) and Vinther (1999). The most probable reason for the high late summer and fall bycatch is the higher abundance of porpoises in the studied area during the summer months in the waters used for gillnet fisheries. Most sightings of porpoises in the German Baltic Sea are during summer months, however, this is also the season with the highest visual survey effort in general (Gilles et al., 2014, 2011; Gilles and Siebert, 2009; Viquerat et al., 2015, Scheidat et al., 2008).

Regarding the spatial distribution of bycatch events and fishing effort, the majority of bycatch occurred in Eckernförde Bight and Schlei, although the highest fishing effort was in ICES square 37G1, where there was hardly any bycatch. The south-western Baltic Sea is also a habitat for the critically endangered Baltic Proper population during winter months (Benke et al., 2014). Since none of the bycaught animals have been tested genetically, we are not able to determine to which population the bycaught animals belong to. However, even one bycaught harbor porpoise from the Baltic Proper population could have a detrimental impact on this population and a zero anthropogenic mortality limit should be aimed for, also justified by the precautionary principle.

Behavioral changes during summer and fall may affect the risk of porpoises being bycaught in a gillnet. Increased bycatch during increased fishing effort from July and December matched our expectations. In contrast, Herr (2009) and Sonntag (2012) noted a higher number of gillnets in the first six months of the year in the same area, and a lower number in July and 
280

281

282

283

284

285

286

287

288

289

290

291

292

293

294

295

296

297

298

299

300

301

302

303

304

305

306

307

308

309

310

311

312

313

314

315

316

317

318

319

August within their observation periods ranging from 2002 to 2008 . From their observations, we would expect to have more bycaught animals during the first six months of the year, which is not corroborated by our data. In fact, we found more than 2.5 times lower bycatch during winter and spring and a higher number in the summer and fall. Nevertheless, given that our findings are based on a limited number of observations of fishing activities, the results from such analyses should be treated with considerable caution.

Harbor porpoises can detect gill nets at a range of at least 5-10 m using echolocation (Kastelein et al., 1999); perhaps at even longer ranges (Nielsen et al. 2012). It is not well understood why bycatch occurs even though the nets should be detectable to the animals at longer distances than when they risk entanglement. Foraging, socialization (e.g., distraction by conspecifics) or weather conditions might influence the probability of porpoises to be bycaught. In addition, the Baltic Sea is an environment with high and increasing amounts of anthropogenic activities such as shipping, constructions, military, recreation, and ammunition deposits (Korpinen et al., 2012; Reusch et al., 2018). Noise disturbances can reduce echolocation of porpoises and cause fleeing behaviors (Dyndo et al., 2015; Wisniewska et al. 2018) which may result in nets not being detected and animals becoming entangled. It is unclear if natural sounds may be correlated to bycatch events by creating distractions (e.g., making the nets less audible to the animals by decreasing the detection distance, or by scaring animals so they accidentally swim into the nets). In our study, neither precipitation nor wind speed had any impact on bycatch. Both precipitation and wind speed increase the ambient noise level and could in theory cause the masking of returning echoes from fishing gear, making it difficult for the porpoise to detect them. However, the very high frequency content of the echoes probably prevents wind and rain from having any effect on the ambient noise at these frequencies.

In addition to weather conditions, we investigated the correlation of moon phases with bycatch. The majority of porpoises were bycaught during a full moon and moonlight night. The tidal changes caused by the different phases of the moon are extremely small in the Baltic Sea. Therefore, the effect of the moon on porpoise bycatch seems driven by variations in light conditions rather than by tidal differences. The lunar cycle also affects fish activity (Takemura et al., 2004; Horký et al., 2006; Celik and Celik, 2011). All this together, it is conceivable that porpoises are hunting more actively during the full moon and, consequently, the risk of swimming into a fishing net is higher. In addition, fishing activities depend on weather and perhaps also lunar conditions. If fishing effort increases during the full moon, this could also explain the high bycatch. Clear lunar patterns were observed in the echolocation activity of IndoPacific humpback dolphins (Sousa chinensis) and of common dolphins (Delphinus delphis) with higher echolocations detections during the new moon (Wang et al., 2015; Simonis et al., 2017). While no studies have analysed the influence of the lunar cycle on wild harbor porpoises, longterm static acoustic monitoring conducted in the Baltic Sea revealed a 29-day rhythm (i.e., synodic period; M. Dähne, 2019, pers. comm). The fact that the clicking activity of captive porpoises is not dependent on lunar cycle (Osiecka et al., 2020) may indicate that this pattern is caused by porpoises adjusting to prey behaviour rather than their clicking behaviour being 
320

321

322

323

\section{4}

325

326

327

328

329

330

331

332

333

334

335

336

337

338

339

340

341

342

\section{3}

344

345

346

347

348

\section{9}

350

351

352

353

354

355

356

357

358

359

360

directly affected by the lunar cycle. While the reasons for such activity cycles remains unknown, more studies focusing on understanding the influence of meteorological factors on bycatch are needed.

\section{Conclusions}

The harbor porpoise is the only cetacean species in the Baltic Sea, and, as a top predator, an important key species and indicator of the health and resilience of the marine ecosystem. The long-term data presented here gives important clues on how environmental parameters in time and space as well as by age- and sex-related factors affects bycatch, a major mortality cause in harbor porpoises. In Germany, to date, there is no established bycatch observation program on small vessels (i.e., $<8 \mathrm{~m}$ ) or for recreational (part-time) fisheries. We may envision that the inclusion of such vessels would make the threat from bycatch even more worrying. In addition, mitigation measures should be updated by including critical time periods (summer months) and areas with high number of bycatch events. To reduce bycatch, fishing efforts could be reduced seasonally between e.g., July and November, especially in areas with high bycatch of juveniles and neonates, such as Eckernförde Bight and Schlei. A more detailed knowledge of the causes of bycatch could result in a more cost-effective regulation of fishing activities. Moreover, considering the potential use of the south-western area in winter by harbor porpoises of the Baltic Proper population, zero bycatch should be allowed. Therefore, future studies on the current status of the Baltic Proper porpoise distribution range (e.g. with genetic studies) are recommended to be able to design management strategies as effective as possible.

\section{Acknowledgements}

The authors wish to thank all dedicated members of the marine mammal stranding response network of Schleswig-Holstein, Germany. Thanks also go to all ITAW colleagues for their support during necropsies and sample collection. This study was partly supported by the Ministry of Energy, Agriculture, the Environment, Nature and Digitization (MELUND).

\section{References}

ASCOBANS Bonn Germany. 2000. Proceedings of the third meeting of parties to ASCOBANS. van Beest FM, Kindt-Larsen L, Bastardie F, Bartolino V, Nabe-Nielsen J. 2017. Predicting the population-level impact of mitigating harbor porpoise bycatch with pingers and time-area fishing closures. Ecosphere 8. DOI: 10.1002/ecs2.1785.

Benke, H., Siebert, U., Lick R, Bandomir-Krischak B, R. W. 1998. The current status of harbour porpoises (Phocoena phocoena) in German waters. Archive of Fisheries and Marine Research 46:97-123.

Benke, H, Bräger, S, Dähne, M, Gallus, A, Hansen, S, Honnef, CG, Jabbusch, M, Koblitz, JC, Krügel, K, Liebschner, A, Narberhaus, I, Verfuß, UK. 2014. Baltic Sea harbour porpoise populations: status and conservation needs derived from recent survey results. Marine ecology progress series: 495: 275-290. 
361

362

363

364

365

366

367

368

369

370

371

372

373

374

375

376

377

378

379

380

381

382

383

384

385

386

387

388

389

390

391

392

393

394

395

396

397

398

399

400

401

402

403

404

405

406

Berggren P. 1994. Bycatches of the harbour porpoise (Phocoena phocoena) in the Swedish Skagerrak, Kattegat and Baltic Seas; 1973-1993. Report of the International whaling Commission:211-215.

Berggren P, Wade PR, Carlström J, Read AJ. 2002. Potential limits to anthropogenic mortality for harbour porpoises in the Baltic region. Biological Conservation 103:313-322.

Berggren, P., Hiby, L., Lovell, P. and Scheidat, M. 2004. Abundance of harbour porpoises in the Baltic Sea from aerial surveys conducted in summer 2002. Paper SC/56/SM7 presented to the IWC Scientific Committee, July 2004, Sorrento, Italy. 16pp.

Bjørge A, Skern-Mauritzen M, Rossmann MC 2013. Estimated bycatch of harbour porpoise (Phocoena phocoena) in two coastal gillnet fisheries in Norway, 2006-2008. Mitigation and implications for conservation. Biological Conservation 161:164-173.

Brownell RL, Reeves RR, Read AJ, Smith BD, Thomas PO, Ralls K, Amano M, Berggren P, Chit AM, Collins T, Currey R, Dolar MLL, Genov T, Hobbs RC, Kreb D, Marsh H, Zhigang M, Perrin WF, Phay S, Rojas-Bracho L, Ryan GE, Shelden KEW, Slooten E, Taylor BL, Vidal O, Ding W, Whitty TS, Wang JY. 2019. Bycatch in gillnet fisheries threatens critically endangered small cetaceansand other aquatic megafauna. Endangered Species Research 40:285-296. DOI: 10.3354/ESR00994.

Carlén I, Nunny L, Simmonds MP. 2021. Out of Sight, Out of Mind: How Conservation Is Failing European Porpoises. Frontiers in Marine Science 8:13. DOI: 10.3389/fmars.2021.617478.

Carlén I, Thomas L, Carlström J, Amundin M, Teilmann J, Tregenza N, Tougaard J, Koblitz JC, Sveegaard S, Wennerberg D, Loisa O, Dähne M, Brundiers K, Kosecka M, Kyhn LA, Ljungqvist CT, Pawliczka I, Koza R, Arciszewski B, Galatius A, Jabbusch M, Laaksonlaita J, Niemi J, Lyytinen S, Gallus A, Benke H, Blankett P, Skóra KE, Acevedo-Gutiérrez A. 2018. Basin-scale distribution of harbour porpoises in the Baltic Sea provides basis for effective conservation actions. Biological Conservation 226:42-53. DOI: 10.1016/j.biocon.2018.06.031.

Celik P, Celik I. 2011. Effect of lunar synchronization on the reproduction time of discus fish (symphysodon sp.) under controlled aquarium conditions. Journal of Animal and Veterinary Advances 10:890-893. DOI: 10.3923/javaa.2011.890.893.

Dähne M, Gilles A, Lucke K, Peschko V, Adler S, Krügel K, Sundermeyer J, Siebert U. 2013. Effects of pile-driving on harbour porpoises (Phocoena phocoena) at the first offshore wind farm in Germany. Environmental Research Letters 8. DOI: 10.1088/1748-9326/8/2/025002.

Dorrien C von, Krumme U, Grieger C, Miethe T, Stötera S. 2013. Analyse fischereilicher Daten in den schleswig-holsteinischen Küstengewässern der Ostsee. Braunschweig: Johann Heinrich von Thünen-Institut:72p.

Dyndo M, Wis̈niewska DM, Rojano-Doñate L, Madsen PT. 2015. Harbour porpoises react to low levels of high frequency vessel noise. Scientific Reports 5:1-9. DOI: 10.1038/srep11083.

Funk S, Krumme U, Temming A, Mo C. 2020. Gillnet fishers' knowledge reveals seasonality in depth and habitat use of cod (Gadus morhua) in the Western Baltic Sea. ICES Journal of Marine Science. DOI: 10.1093/icesjms/fsaa071.

Gilles A, Peschko V, Siebert U. 2011. Monitoringbericht 2010-2011. Marine Säugetiere und Seevögel in der deutschen AWZ von Nord- und Ostsee. Teilbericht marine Säugetiere. Final report for Federal Agency for Nature Conservation, p 5-73 [in German with English summary]. https://tinyurl.com/y4u6axyl. 
407

408

409

410

411

412

413

414

415

416

417

418

419

420

421

422

423

424

425

426

427

428

429

430

431

432

433

434

435

436

437

438

439

440

441

442

443

444

445

446

447

448

449

450

451

452

Gilles A, Siebert U. 2009. Erprobung eines Bund/Länder-Fachvorschlags für das Deutsche Meeresmonitoring von Seevögeln und Schweinswalen als Grundlage für die Erfüllung der Natura 2000 - Berichtspflichten mit einem Schwerpunkt in der deutschen AWZ von Nordund Ostsee, p 5-30 [in German with English summary]. https://tinyurl.com/y6n62yek.

Gilles A, Viquerat S, Siebert U. 2014. Monitoring von marinen Säugetieren 2013 in der deutschen Nord- und Ostsee. Visuelle Erfassung von Schweinswalen. Final report for Federal Agency for Nature Conservation, p 1-53 [in German with English summary]. https://tinyurl.com/y3yhqxru

Hammond PS, Berggren P, Benke H, Borchers DL, Collet A, Heide-Jørgensen MP, Heimlich S, Hiby a. R, Leopold MF, Øien N. 2002. Abundance of harbour porpoise and other cetaceans in the North Sea and adjacent waters. Journal of Applied Ecology 39:361-376. DOI: 10.1046/j.1365-2664.2002.00713.x.

Hammond, P.S., Lacey, C., Gilles, A., Viquerat, S., Börjesson, P., Herr, H., Macleod, K., Ridoux, V., Santos, M.B., Scheidat, M., Teilmann, J., Vingada, J., Øien, N. (2017). Estimates of cetacean abundance in European Atlantic waters in summer 2016 from the SCANS-III aerial and shipboard surveys. $40 \mathrm{pp}$. https://synergy.standrews.ac.uk/scans3/files/2017/05/SCANS-III-design-based- estimates-2017-05-12- finalrevised.pdf.

Hammond PS, Macleod K, Berggren P, Borchers DL, Burt L, Cañadas A, Desportes G, Donovan GP, Gilles A, Gillespie D, Gordon J, Hiby L, Kuklik I, Leaper R, Lehnert K, Leopold M, Lovell P, Øien N, Paxton CGM, Ridoux V, Rogan E, Samarra F, Scheidat M, Sequeira M, Siebert U, Skov H, Swift R, Tasker ML, Teilmann J, Van Canneyt O, Vázquez JA. 2013. Cetacean abundance and distribution in European Atlantic shelf waters to inform conservation and management. Biological Conservation 164:107-122. DOI: 10.1016/j.biocon.2013.04.010.

HELCOM. 2018. State of the Baltic Sea - Second HELCOM holistic assessment 2011-2016. altic Sea Environment Proceedings 155.

Herr H. 2009. Vorkommen von Schweinswalen (Phocoena phocoena) in Nord- und Ostsee - im Konflikt mit Schifffahrt und Fischerei? Dissertation, Universität Hamburg.

Horký P, Slavík O, Bartoš L, Kolářová J, Randák T. 2006. The effect of the moon phase and seasonality on the behaviour of pikeperch in the Elbe River. Folia Zoologica 55:411-417.

IJsseldijk LL, Scheidat M, Siemensma M, Couperus B, Leopold MF, Morell M, Grone A, Kik MJL. 2020. Challenges in the assessment of bycatch: Post-mortem findings in harbor porpoises (Phocoena phocoena) retrieved from gillnets. Veterinary Pathology. DOI: 10.1177/0300985820972454.

Kastelein RA, Au WWL, de Haan D. 2000. Detection distances of bottom-set gillnets by harbour porpoises (Phocoena phocoena) and bottlenose dolphins (Tursiops truncatus). Marine environmental research 49:359-375. DOI: 10.1016/S0141-1136(99)00081-1.

Kastelein RA, Au WWL, Rippe T, M. SN. 1999. Transmission beam pattern and echolocation signals of a harbour porpoises (Phocoena phocoena). Journal of Acoustical Society of America 106:3699-3705.

Kesselring T, Viquerat S, Brehm R, Siebert U. 2018. Coming of age: - Do female harbour porpoises (Phocoena phocoena) from the North Sea and Baltic Sea have sufficient time to reproduce in a human influenced environment? PLOS ONE 13:1-14. DOI:

10.1371/journal.pone.0199633.

Kinze CC. 1994. Incidental catches of harbour porpoises (Phocoena phocoena) in Danish waters

Peer] reviewing PDF | (2021:03:58695:3:0:NEW 30 Aug 2021) 
453

454

455

456

457

458

459

460

461

462

463

464

465

466

467

468

469

470

471

472

473

474

475

476

477

478

479

480

481

482

483

484

485

486

487

488

489

490

491

492

493

494

495

496

1986-89. Rep Int Whal Comm (Spec Issue) 15:183-188.

Kock KH, Benke H. 1996a. On the by-catch of harbour porpoise (Phocoena phocoena) in German fisheries in the Baltic and the North Sea. Arch Fish Mar Res 44:95-114.

Kock K-H, Benke H. 1996b. By-catch of harbour porpoises ( Phocoena phocoena ) in the Baltic coastal waters of Angeln and Schwansen ( Schleswig-Holstein, Germany ). ASCOBANS $/ A D V . C O M / 2 / D O C .1$.

Königson S, Fredriksson RE, Lunneryd SG, Strömberg P, Bergström UM. 2015. Cod pots in a Baltic fishery: are they efficient and what affects their efficiency? ICES Journal of Marine Science 72(5):1545-1554. DOI: 10.1093/icesjms/fsu230.

Korpinen S, Meski L, Andersen JH, Laamanen M. 2012. Human pressures and their potential impact on the Baltic Sea ecosystem. Ecological Indicators 15:105-114. DOI:

10.1016/j.ecolind.2011.09.023.

Koschinski S. 2001. Current knowledge on harbour porpoises ( Phocoena phocoena ) in the Baltic Sea. Ophelia 55:167-197. DOI: 10.1080/00785326.2001.10409483.

Koschinski S, Pfander A. 2009. By-catch of harbour porpoises ( Phocoena phocoena) in the Baltic coastal waters of Angeln and Schwansen ( Schleswig-Holstein, Germany ). Nature 60:20-24.

Kratzer IMF, Schäfer I, Stoltenberg A, Chladek JC, Kindt-Larsen L, Larsen F, Stepputtis D. 2020. Determination of Optimal Acoustic Passive Reflectors to Reduce Bycatch of Odontocetes in Gillnets. Frontiers in Marine Science 7:1-18. DOI: 10.3389/fmars.2020.00539.

Kremer H. 1987. Untersuchungen zur Altersbestimmung an Schweinswalen (Phocoena phocoena) (Lin. 1758). Diplomarbeit der Universität Kiel (unpublished). University of Kiel. [In German] Available from the IfM of the Univeristy of Kiel.

Lockyer C. 1995. A review of factors involved in zonation in odontocete teeth, and an investigation of the likely impact of environmental factors and major life events on harbour porpoise tooth structure. Biology of the Phocoenids. Rep. Int. Whal. Comm. Spec. 16:511527.

Lockyer C. 2003. Harbour porpoises (Phocoena phocoena) in the North Atlantic: Biological parameters. NAMMCO Scientific Publications 5:71. DOI: 10.7557/3.2740.

Løkkeborg S, Fernö A. 1999. Diel activity pattern and food search behaviour in cod, Gadus morhua. Environmental Biology of Fishes 54:345-353. DOI: 10.1023/A:1007504712163.

Moan A, Skern-Mauritzen M, Vølstad JH, Bjørge A. 2020. Assessing the impact of fisheriesrelated mortality of harbour porpoise (Phocoena phocoena) caused by incidental bycatch in the dynamic Norwegian gillnet fisheries. ICES Journal of Marine Science 77 (7-8), 30393049. DOI: 10.1093/icesjms/fsaa186.

Myrick AC, Hohn AA, Sloan PA, Kimura M, Stanley DD. 1983. Estimating age of spotted and spiner dolphins (Stenella attenuata and Stenella longirostris) from teeth. National Oceanic and Atmospheric Administration Technical Report NMFS 30, National Marine Fisheries Service, US Department of Commerce, Silver Springs, Maryland:1-17.

Nielsen, TP, Wahlberg, M, Heikkilä, S, Jensen, M, Sabinsky, P, Dabelsteen, T. 2012. Swimming patterns of wild harbour porpoises Phocoena phocoena show detection and avoidance of gillnets at very long ranges. Marine ecology progress series 453: 241-248. DOI: 10.3354/meps09630

Peer] reviewing PDF | (2021:03:58695:3:0:NEW 30 Aug 2021) 
497

498

499

500

501

502

503

504

505

506

507

508

509

510

511

512

513

514

515

516

517

518

519

520

521

522

523

524

525

526

527

528

529

530

531

532

533

534

535

536

537

538

539

540

541

542

North Atlantic Marine Mammal Commission and the Norwegian Institute of Marine Research (NAMMCO and NIMR). (2019). Report of Joint IMR/NAMMCO International Workshop on the Status of Harbor Porpoises in the North Atlantic. Tromsø, Norway.

Nystuen JA. 1986. Rainfall measurements using underwater ambient noise. Journal of the Acoustical Society of America 79:972-982. DOI: 10.1121/1.393695.

OIC. 2015. Freiwillige Vereinbarung zum Schutz von Schweinswalen und tauchenden Meeresenten Zwischenbericht.

Osiecka AN, Jones O, Wahlberg M. 2020. The diel pattern in harbour porpoise clicking behaviour is not a response to prey activity. Scientific Reports 10:1-7. DOI:

10.1038/s41598-020-71957-0.

Owen K, Andrews RD, Baird RW, Schorr GS, Webster DL. 2019. Lunar cycles influence the diving behavior and habitat use of short-finned pilot whales around the main Hawaiian Islands. Marine ecology progress series 629: 193-206. DOI: 0.3354/meps13123

Palacino González, G. 2019. Social interactions of wild harbour porpoises (Phocoena phocoena) studied with unmanned aerial vehicles. Master thesis. Institute of Biology, University of Southern Denmark

Pensieri S, Bozzano R, Nystuen JA, Anagnostou EN, Anagnostou MN, Bechini R. 2015. Underwater acoustic measurements to estimate wind and rainfall in the mediterranean sea. Advances in Meteorology 2015. DOI: 10.1155/2015/612512.

Perrin WF, Donovan GP, Barlow J. 1994. Gillnets and Cetaceans. International Whaling Commission.

Read AJ, Drinker P, Northridge S. 2006. Bycatch of marine mammals in U.S. and global fisheries. Conservation Biology 20:163-169. DOI: 10.1111/j.1523-1739.2006.00338.x.

Reeves RR, McClellan K, Werner TB. 2013. Marine mammal bycatch in gillnet and other entangling net fisheries, 1990 to 2011. Endangered Species Research 20:71-97. DOI: 10.3354/esr00481.

Reusch TBH, Dierking J, Andersson HC, Bonsdorff E, Carstensen J, Casini M, Czajkowski M, Hasler B, Hinsby K, Hyytiäinen K, Johannesson K, Jomaa S, Jormalainen V, Kuosa H, Kurland S, Laikre L, MacKenzie BR, Margonski P, Melzner F, Oesterwind D, Ojaveer H, Refsgaard JC, Sandström A, Schwarz G, Tonderski K, Winder M, Zandersen M. 2018. The Baltic Sea as a time machine for the future coastal ocean. Science Advances 4. DOI: 10.1126/sciadv.aar8195.

Rogan E, Read AJ, Berggren P. 2021. Empty promises: The European Union is failing to protect dolphins and porpoises from fisheries by-catch. Fish and Fisheries 00:1-5. DOI: $10.1111 /$ faf. 12556

Rubsch S, Kock K-H. 2004. German part - time fishermen in the Baltic Sea and their by - catch of harbour porpoise. Paper presented to the 11th ASCOBANS Advisory Com- mittee Meeting, 27-29 April 2004, Jastrzebia Góra.

Santos MB, Pierce GJ. 2003. The diet of harbour porpoise (Phocoena Phocoena) in the Northeast Atlantic. Oceanography and Marine Biology: an Annual Review 41:355-390.

Scheidat M, Gilles A, Kock KH, Siebert U. 2008. Harbour porpoise Phocoena phocoena abundance in the southwestern Baltic Sea. Endangered Species Research 5:215-223. DOI: $10.3354 /$ esr00161.

Siebert U, Wünschmann A, Weiss R, Frank H, Benke H, Frese K. 2001. Post-mortem Findings in Harbour Porpoises ( Phocoena phocoena ) from the German North and Baltic Seas. Journal of Comparative Pathology 124:102-114. DOI: 10.1053/jcpa.2000.0436

Peer] reviewing PDF | (2021:03:58695:3:0:NEW 30 Aug 2021) 
543

544

545

546

547

548

549

550

551

552

553

554

555

556

557

558

559

560

561

562

563

564

565

566

567

568

569

570

571

572

573

574

575

576

577

578

579

580

581

582

583

584

585

586

587

588

Siebert U, Gilles A, Lucke K, Ludwig M, Benke H, Kock KH, Scheidat M. 2006. A decade of harbour porpoise occurrence in German waters-Analyses of aerial surveys, incidental sightings and strandings. Journal of Sea Research 56:65-80. DOI: 10.1016/j.seares.2006.01.003.

Siebert U, Pawliczka I, Benke H, von Vietinghoff V, Wolf P, Pilāts V, Kesselring T, Lehnert K, Prenger-Berninghoff E, Galatius A, Anker Kyhn L, Teilmann J, Hansen MS, Sonne C, Wohlsein P. 2020. Health assessment of harbour porpoises (PHOCOENA PHOCOENA) from Baltic area of Denmark, Germany, Poland and Latvia. Environment International 143. DOI: 10.1016/j.envint.2020.105904.

Simonis AE, Roch MA, Bailey B, Barlow J, Clemesha RES, Iacobellis S, Hildebrand JA, Baumann-Pickering S. 2017. Lunar cycles affect common dolphin Delphinus delphis foraging in the Southern California Bight. Marine Ecology Progress Series 577:221-235. DOI: $10.3354 /$ meps 12247.

Sonntag N, Schwemmer H, Fock HO, Bellebaum J, Garthe S. 2012. Seabirds, set-nets, and conservation management: assessment of conflict potential and vulnerability of birds to bycatch in gillnets. ICES Journal of Marine Science 69(4), 578-589. DOI:

10.1093/icesjms/fss030

Sveegaard S, Teilmann J, Tougaard J, Dietz R, Mouritsen KN, Desportes G, Siebert U. 2011. High-density areas for harbor porpoises (Phocoena phocoena) identified by satellite tracking. Marine Mammal Science 27:230-246. DOI: 10.1111/j.1748-7692.2010.00379.x.

Takemura A, Rahman S, Nakamura S, Park YJ, Takano K. 2004. Lunar cycles and reproductive activity in reef fishes with particular attention to rabbitfishes. Fish and Fisheries 5:317-328.

Tougaard J, Henriksen OD, Miller LA. 2009. Underwater noise from three types of offshore wind turbines: Estimation of impact zones for harbor porpoises and harbor seals. The Journal of the Acoustical Society of America 125:3766-3773. DOI: 10.1121/1.3117444.

Tregenza NJC, Berrow SD, Hammond PS, Leaper R. 1997. Harbour porpoise (Phocoena phocoena L.) by-catch in set gillnets in the Celtic Sea. ICES J. Mar. Sci. 54:896-904. DOI: 10.1006/jmsc. 1996.0212.

Vinther M. 1999. Bycatches of harbour porpoises (Phocoena phocoena L.) in Danish set-net fisheries. Journal of Cetacean Research and Management 1(2):123-135

Vinther M, Larsen F. 2004. Updated estimates of harbour porpoise (Phocoena phocoena) bycatch in the Danish North Sea bottom-set gillnet fishery. Journal of Cetacean Research and Management 6:19-24.

Viquerat S, Gilles A, Herr H, Siebert U. 2015. Monitoring von marinen Säugetieren 2014 in der deutschen Nord- und Ostsee. Visuelle Erfassung von Schweinswalen. Final report for Federal Agency for Nature Conservation. :1-58 [in German].

Vishnyakova K., Gol'din P. 2014. Seasonality of strandings and bycatch of harbour porpoises in the Sea of Azov: the effects of fisheries, weather conditions, and life history. ICES Journal ofMarine Science 72:981-991. DOI: 10.1093/icesjms/fsu192

Wang ZT, Nachtigall PE, Akamatsu T, Wang KX, Wu YP, Liu JC, Duan GQ, Cao HJ, Wang D. 2015. Passive acoustic monitoring the diel, lunar, seasonal and tidal patterns in the biosonar activity of the Indo-Pacific humpback dolphins (Sousa chinensis) in the Pearl River Estuary, China. PLoS ONE 10:1-24. DOI: 10.1371/journal.pone.0141807.

Wickham H. 2016. ggplot2: Elegant Graphics for Data Analysis. Springer-Verlag New York.

Wisniewska DMM, Johnson M, Teilmann J, Rojano-Doñate L, Shearer J, Sveegaard S, Miller LAA, Siebert U, Madsen PTT. 2016. Ultra-High Foraging Rates of Harbor Porpoises Make

Peer) reviewing PDF | (2021:03:58695:3:0:NEW 30 Aug 2021) 
589

590

591

592

593

594

595

596

597

598

599

600

601

602

603

604

605

606

Them Vulnerable to Anthropogenic Disturbance. Current Biology 26:1441-1446. DOI: 10.1016/j.cub.2016.03.069.

Wisniewska DM, Johnson M, Teilmann J, Siebert U, Galatius A, Dietz R, Madsen PT. 2018. High rates of vessel noise disrupt foraging in wild harbour porpoises ( Phocoena phocoena ). Proceedings of the Royal Society B: Biological Sciences 285:20172314. DOI: 10.1098/rspb.2017.2314.

Wünschmann A, Frese K, Muiller G, Baumgartner W, Siebert U, Weiss R, Lockyer C, HeideJorgensen MP. 2001. Evidence of infectious diseases in harbour porpoises (Phocoena phocoena) hunted in the waters of Greenland and by-caught in the German North Sea and Baltic Sea. Veterinary Record 148:715-720. DOI: 10.1136/vr.148.23.715. 


\section{Legends of figures}

608

609

610

Fig. 1: Bycatches of harbor porpoises from 1987-2016.

611 Holstein from 1987-2016, $(\mathrm{n}=140)$, dashed line: polynomial regression equation: $\mathrm{y}=6 \mathrm{E}-05 \mathrm{x}^{5}-$ $6120.6374 x^{4}+2552.6 x^{3}-5 E+06 x^{2}+5 E+09 x-2 E+12$, Multiple $R^{2}: 0.51, p<0.001$.

613 Fig. 2: Seasonal distribution of harbor porpoise bycatches.

614 Seasonal distribution of age groups and sexes of harbor porpoise bycatches off the German Baltic 615 Sea coast of Schleswig-Holstein in the period from $1987-2016$ (bar chart, $\mathrm{n}=136$ ), seasonal 616 distribution of fishing effort in days at sea (solid line, monthly averages of the years 2010 - 2012; 617 based on Dorrien et al. 2013) and bycatch rate (dashed line, bycatch per fishing effort). Four 618 animals were excluded from the data set due to inconclusive age determination.

619 Fig. 3: Spatial distribution of harbor porpoise bycatches and fishing effort.

620 Bycatches of harbor porpoises summed per grid cell $(10 \times 10 \mathrm{~km})$ from 1987 - 2016. (coordinate 621 system ETRS89LAEA, Pseudo Mercator WGS 84, EPSG 3857). Gray dots indicate harbor 622 porpoise bycatch locations. Cross indicates location of lunar cycle data at $54^{\circ} 30^{\prime} \mathrm{N}, 10^{\circ} 20^{\prime} \mathrm{E}$ 623 obtained from the US Naval Observatory. Fishing boats indicate the annual fishing effort in 624 respective ICES squares (annual average of the years 2010 - 2012; based on Dorrien et al. 2013).

625 Fig. 4: The role of environmental conditions on bycatch events.

626 A: Maximum daily wind speed measured in $\mathrm{m} / \mathrm{s}$ at all nine weather stations during bycatch events $627(\mathrm{n}=75)$ and during days with no bycatch $(\mathrm{n}=52,714)$. B: Precipitation in mm measured at all nine 628 weather stations during bycatch events $(n=115)$ and during days with no bycatch $(n=68,435)$.

629 Fig. 5: Number of bycaught harbor porpoises during different lunar phases.

630 Lunar phase during bycatch events $(n=140)$ at $54^{\circ} 30^{\prime} \mathrm{N}, 10^{\circ} 20^{\prime} \mathrm{E}$, one hour ahead of Greenwich 631 Mean Time (GMT); 1: new moon, 2: waxing crescent, 3: first quarter, 4: waxing gibbous, 5: full 632 moon, 6: waning gibbous, 7: last quarter, 8: waning crescent. 
Figure 1

Fig. 1: Bycatches of harbor porpoises from 1987-2016.

Annual variation in number of harbor porpoise bycatches off the Baltic Sea coast of Schleswig-Holstein from 1987-2016, $(n=140)$, dashed line: polynomial regression equation: $y=6 E-05 x^{5}-0.6374 x^{4}+2552.6 x^{3}-5 E+06 x^{2}+5 E+09 x-2 E+12$, Multiple $R^{2}: 0.51, p<0.001$

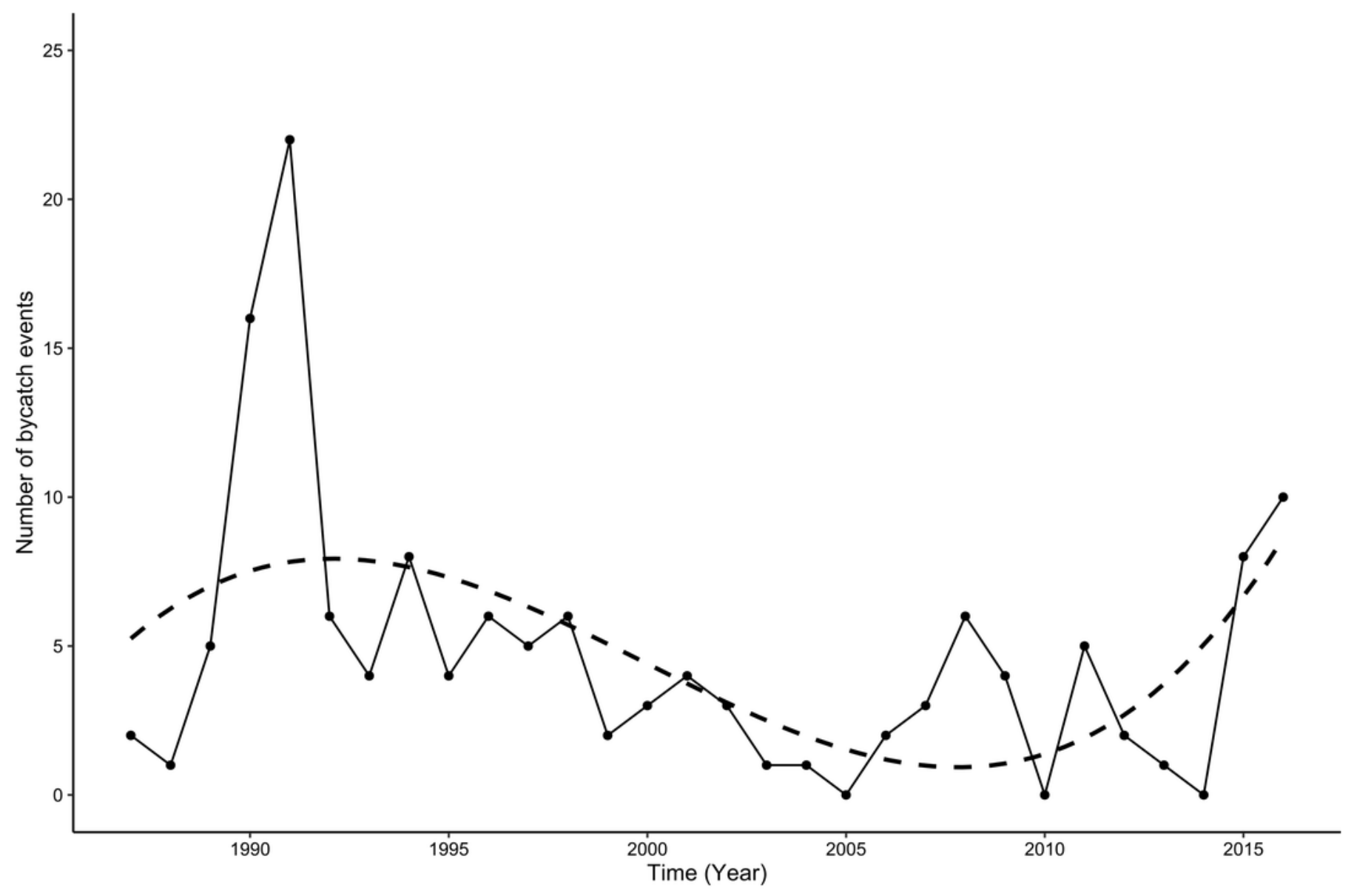


Figure 2

Fig. 2: Seasonal distribution of harbor porpoise bycatches.

Seasonal distribution of age groups and sexes of harbor porpoise bycatches off the German Baltic Sea coast of Schleswig-Holstein in the period from 1987 - 2016 (bar chart, $n=136$ ), seasonal distribution of fishing effort in days at sea (solid line, monthly averages of the years 2010 - 2012; based on Dorrien et al. 2013) and bycatch rate (dashed line, bycatch per fishing effort). Four animals were excluded from the data set due to inconclusive age determination.

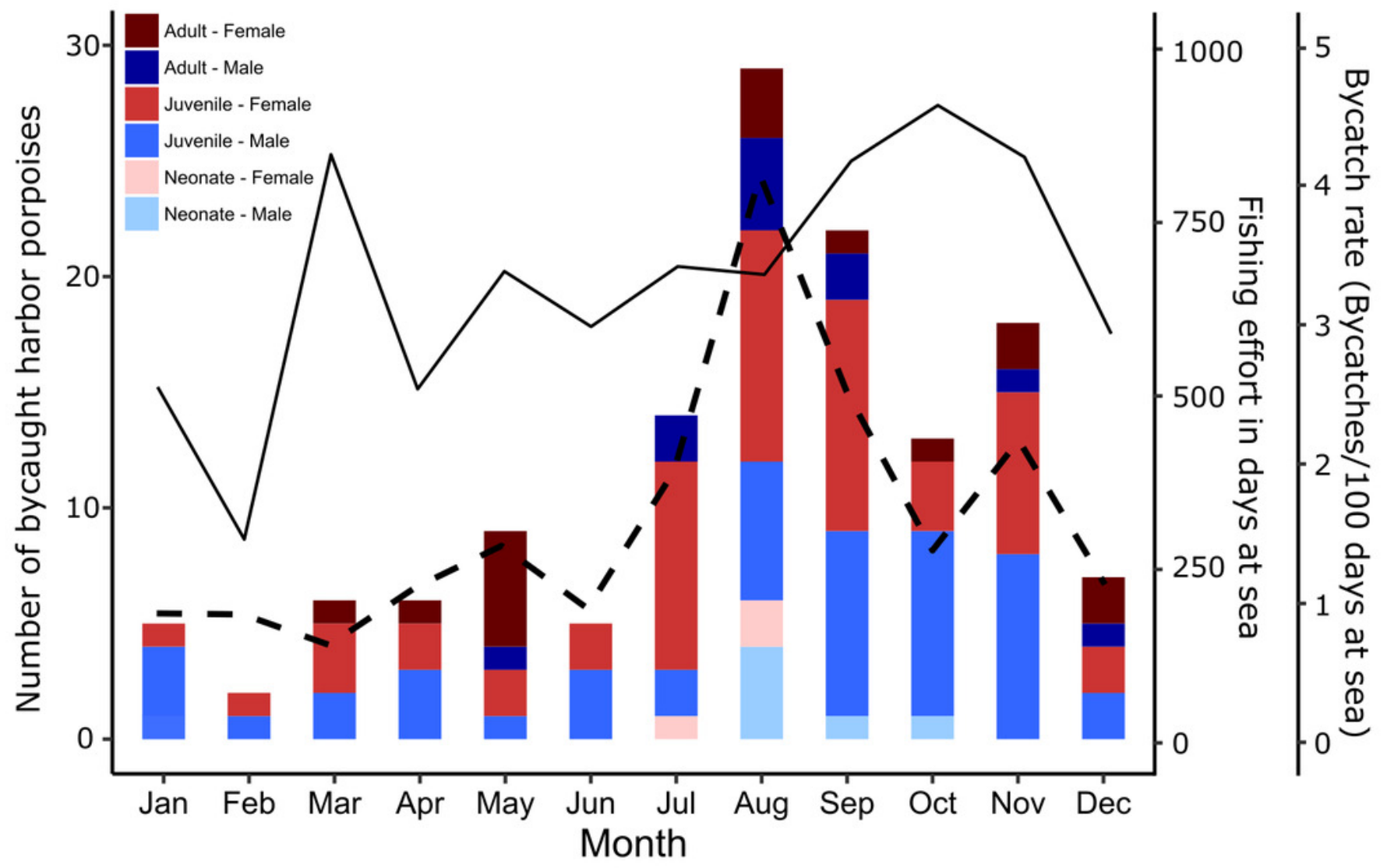




\section{Figure 3}

Fig. 3

Fig. 3: Spatial distribution of harbor porpoise bycatches and fishing

effort.Bycatches of harbor porpoises summed per grid cell (10x10 km) from $1987-2016$.

(coordinate system ETRS89LAEA, Pseudo Mercator WGS 84, EPSG 3857). Gray dots indicate harbor porpoise bycatch locations. Cross indicates location of lunar cycle data at $54^{\circ} 30^{\prime} \mathrm{N}$, $10^{\circ} 20^{\prime} \mathrm{E}$ obtained from the US Naval Observatory. Fishing boats indicate the annual fishing effort in respective ICES squares (annual average of the years 2010 - 2012; based on Dorrien et al. 2013). 


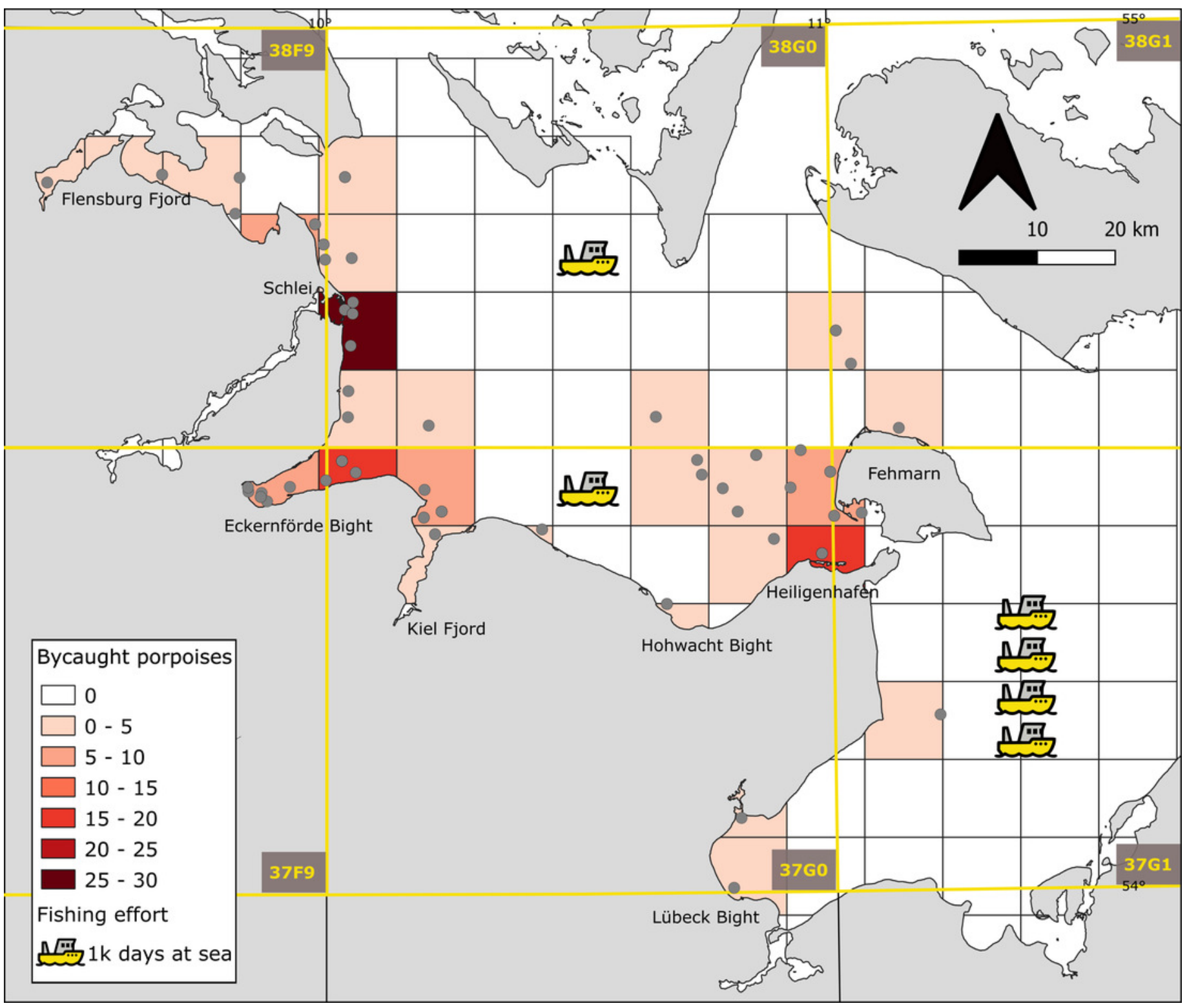


Figure 4

Fig. 4:

Fig. 4: The role of environmental conditions on bycatch events. A: Maximum daily wind speed measured in $\mathrm{m} / \mathrm{s}$ at all nine weather stations during bycatch events $(n=75)$ and during days with no bycatch $(n=52.714)$. B: Precipitation in $\mathrm{mm}$ measured at all nine weather stations during bycatch events $(n=115)$ and during days with no bycatch $(n=$ 68.435), $y$ axis is in a $\log _{10}$ scale.
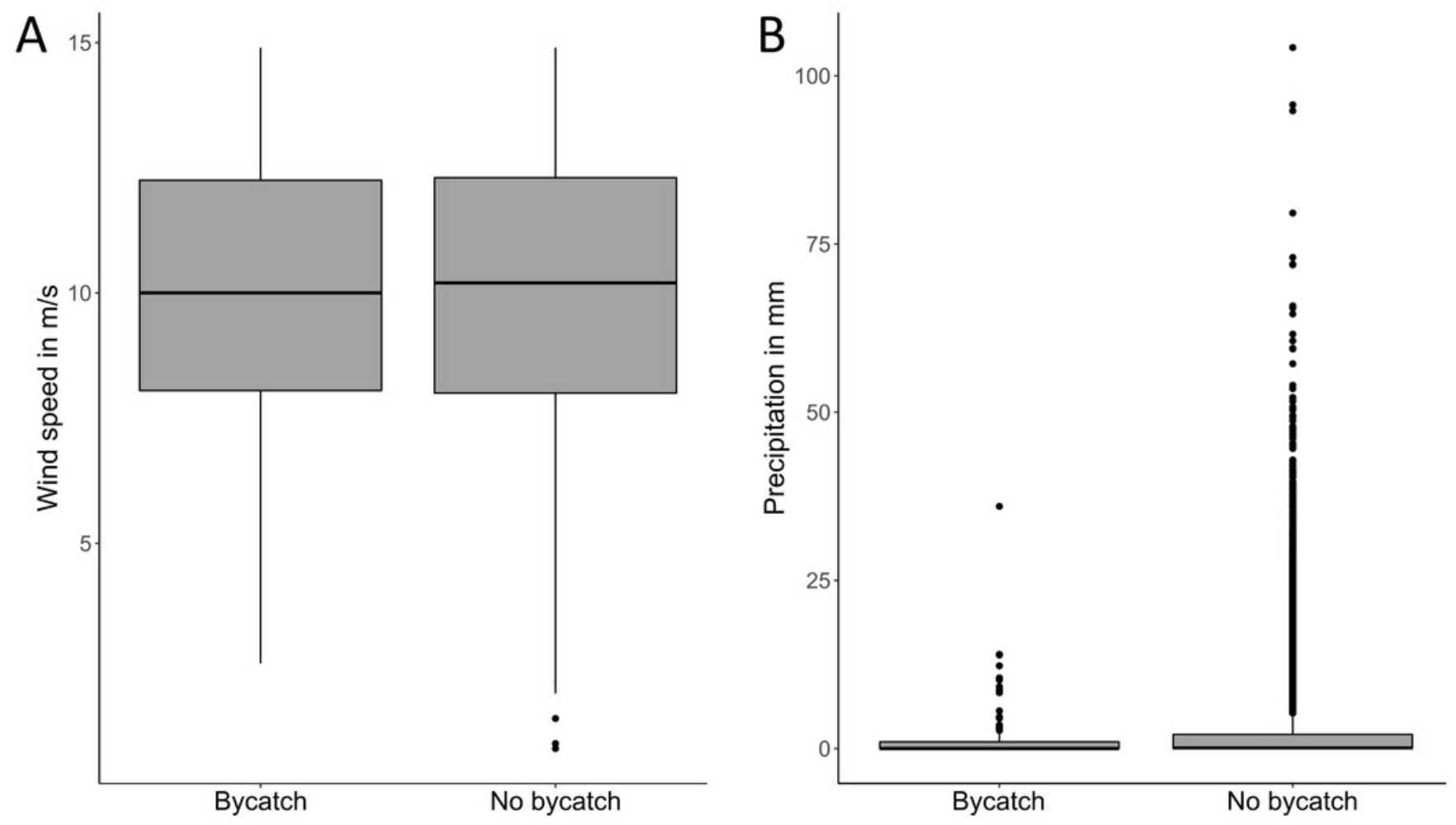


\section{Figure 5}

Fig. 5

Fig. 5: Number of bycaught harbor porpoises during different lunar phases.Lunar phase during bycatch events $(n=140)$ at $54^{\circ} 30^{\prime} N, 10^{\circ} 20^{\prime} E$, one hour ahead of Greenwich Mean Time (GMT); 1: new moon, 2: waxing crescent, 3: first quarter, 4: waxing gibbous, 5: full moon, 6: waning gibbous, 7: last quarter, 8: waning crescent.

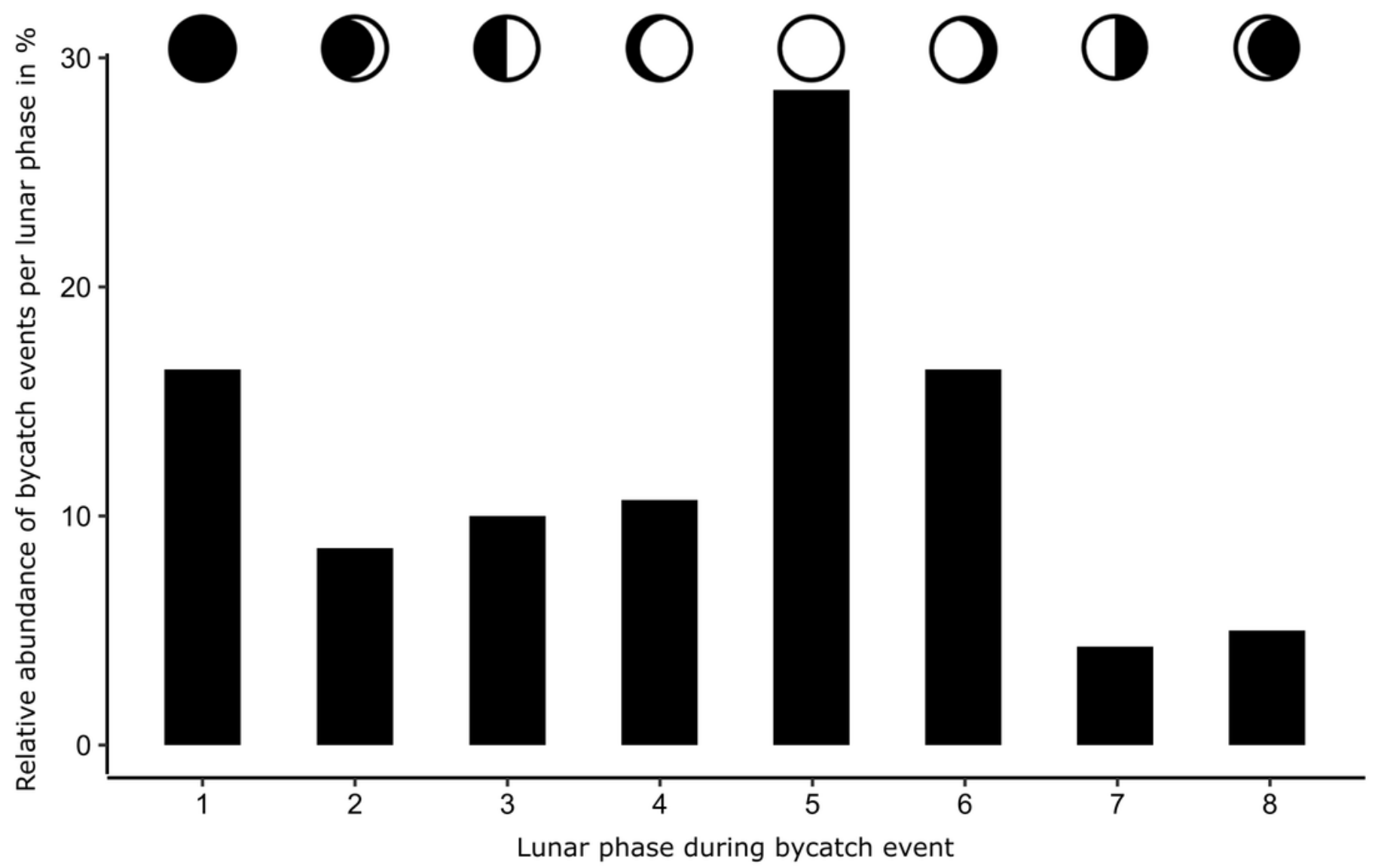




\section{Table $\mathbf{1}$ (on next page)}

Table 1

Table 1: Bycatch of harbor porpoise (Phocoena phocoena) per region. Bycatch of harbor porpoise (Phocoena phocoena) per region of the south-western Baltic Sea (SchleswigHolstein) from 1987 - $2016(n=135)$. Five animals were excluded from this data set due to unknown bycatch location. The regions are ordered from west to east along the coast (see also Fig. 3). 
1 Table 1: Bycatch of harbor porpoise (Phocoena phocoena) per region.

2 Bycatch of harbor porpoise (Phocoena phocoena) per region of the south-western Baltic Sea

3 (Schleswig-Holstein) from $1987-2016(n=135)$. Five animals were excluded from this data set

4 due to unknown bycatch location. The regions are ordered from west to east along the coast (see

5 also Fig. 3).

\begin{tabular}{lcc} 
Region & Bycaught porpoises & $\%$ \\
\hline Flensburg Fjord & 22 & 16.3 \\
Schlei & 27 & 20.0 \\
Eckernförde Bight & 29 & 21.5 \\
Kiel Fjord & 13 & 9.6 \\
Hohwacht Bight & 8 & 5.9 \\
Heiligenhafen & 19 & 14.1 \\
Fehmarn & 14 & 10.4 \\
Lübeck Bight & 135 & 2.2 \\
\hline Total & 3 & 100 \\
\hline
\end{tabular}

